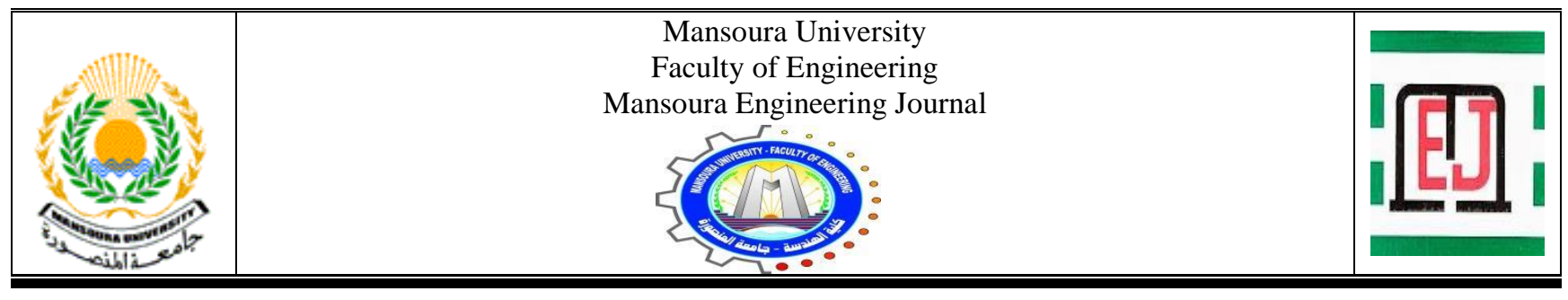

\title{
Rehabilitation of Road Networks inside Inherent Neighborhoods and their Impact on Residents' Urban Quality of Life Case Study: "Heliopolis" Neighborhood-Cairo
}

\author{
Eslam N. Elsayed
}

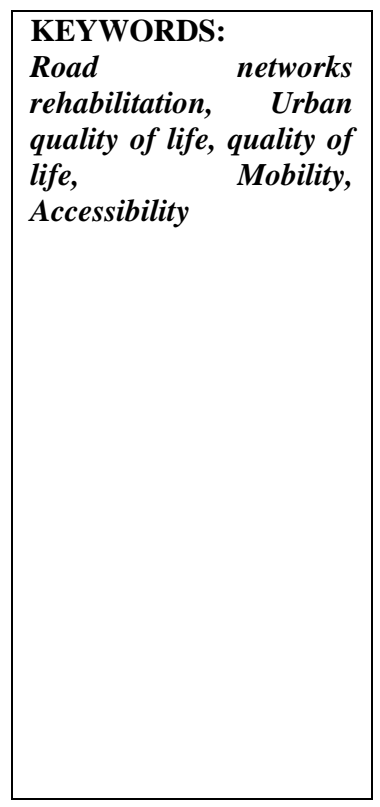

Abstract-The Belgian Baron Empain established "Heliopolis"
neighborhood, and it houses the palace known by his name "Baron's Palace".
Since the eighties, urban expansions and new cities spread east of Cairo on both
sides of the Suez Road, which gave these new cities a strategic location between
the capital and the port of Suez. Recently the Egyptian government is
rehabilitating road networks to accommodate the movement of vehicles from the
new cities east of Cairo to easily integrate them into Cairo itself.
The aim of the research is to identify physical/non-physical dimensions of the
road networks rehabilitation which affecting the urban quality of life. The
research methodology relies on an inductive approach to acknowledge the
concept of Rehabilitation, Egypt's vision 2030 , human needs and satisfaction
versus the Quality of Life (QoL) and the relationship between dimensions of
quality of life and urban quality of life (QoL) for community individuals. It also
applied an analytical method in the study to conduct residents' views before and
after road networks rehabilitation in order to know the effect of the
rehabilitation of road networks on the urban quality of life.
Finally, the research concluded by set of results determining the impact of
road networks rehabilitation on each dimension of urban quality of life. To
achieve mobility urban QoL sufficiently, the expansion of road must not be on
urban elements or urban spaces, and the concept of mobility should include all
types of vehicles and pedestrians.

\section{INTRODUCTION}

$\mathrm{E}$ GYPT'S Vision 2030 is based on the principles of "comprehensive sustainable development" and "balanced regional development". It has the goal to improve the quality of life of Egyptian citizens and improve their standard of living through an integrated development

Received: (25 January, 2021) - Revised: (28 February, 2021) - Accepted: (15 March, 2021)

Corresponding Author: Eslam Nazmy S. Elsayed, Associate Prof. in Department of Architecture Eng., Shoubra Faculty of Eng., Benha University, Cairo,Egypt.(islam.alsayed@feng.bu.edu.eg)(amreslam@yahoo.com) system. Recently the Egyptian government is rehabilitating roads to accommodate the movement of vehicles from the new cities east of Cairo to easily integrate them into Cairo itself. In the same context, the Egyptian government has developed the road networks within the "Heliopolis" neighborhoods

The Belgian Baron Empain established "Heliopolis" neighborhood, and it houses the palace known by his name "Baron's Palace". It characterized the neighborhood by huge and luxurious buildings and metro lines that belonged to a Belgian company until nationalization in the sixties of the twentieth century. Urbanization characterized the "Heliopolis" suburb distinguished by its planning and implementation by providing housing, necessary public facilities, wide roads, and many parks. With the continuation of the construction and urbanization movement, the "Heliopolis" neighborhood 
expanded until the governor of Cairo separated the Nozha district from the "Heliopolis" neighborhood on the first of July 1999 (Akaar Map, 2020).

\section{A. Research problem}

Rehabilitation of road networks within inherent neighborhoods in Greater Cairo Region, to solve traffic crises and maintain traffic flow has had a great impact on the existing inherent neighborhoods and on resident's sense of the urban quality of life. The research raises a set of questions, including:

- What is physical/non-physical dimensions to perceive road networks rehabilitation within any neighborhood?

- How has the rehabilitation of road networks affected residents' neighborhood urban image?

- What is the impact of road networks rehabilitation on urban quality of life?

\section{B. Research aim}

The research aims are:

- Discover the physical/non-physical dimensions of the road networks rehabilitation which effecting on urban quality of life.

- Identify a proposed model to evaluate or execute road networks rehabilitation with resident's satisfaction.

\section{Research Methodology}

The research methodology is based on:

Inductive approach:

1. Theoretical study has two main axes: -

Firstly: by identifying Concept of Rehabilitation, Egypt's vision 2030, human needs and satisfaction and the relationship between physical forms/ dimensions of perceiving urban spaces and quality of life.

Secondly: by discussing physical and non-physical dimensions of the road networks rehabilitation. Explaining the relationship between dimensions of road networks rehabilitation and urban quality of life.

2. Analytical approach:

Analytical approach was applied by:

Analyzing the new road networks in "Heliopolis" neighborhood before and after rehabilitation. Interviews with "Heliopolis" residents to investigate their satisfaction around physical/ non-physical dimensions before and after rehabilitation of road networks, and what effect do road networks have on their quality of life. As well as conducting questionnaires with neighborhood residents to document their point of view on the impact of road networks on their urban quality of life. The study sample included 20 individuals in the interviews and 30 individuals in questionnaires, all applied samples which among them had their advantages that included:

- Diversity between men and women.

- Residents of the neighborhood for at least the last three decades.

\section{THEORETICAL FRAMEWORK FOR THE STUDY}

The theoretical framework of the study includes identifying the concept of Rehabilitation, Egypt's vision 2030,
Greater Cairo region road network, human needs and satisfaction versus the Quality of Life (QoL), and the relationship between dimensions of quality of life and urban quality of life $(\mathrm{QoL})$ for community individuals.

\section{A. Concept of Rehabilitation}

World health organization (WHO) defined rehabilitation as "a set of interventions designed to optimize functionality and accommodate the disabilities in individuals with health conditions in interaction with their environment" (WHO, 2020).

In Merriam-Webster, rehabilitation is "the restoration of something damaged or deteriorated to a prior excellent condition".

Otherwise, the benefits of road rehabilitation have roughly halved trip times and caused vehicle operating costs to fall by an average of about $20 \%$. But a significant adverse effect has been the rapid increase in road accidents on the rehabilitated roads (ADB, 2005).

\section{B. Egypt's Vision 2030}

Egypt's Vision 2030, a national agenda launched in February 2016, reflects the country's long-term strategic plan to achieve the goals and principles of sustainable development in all areas. Egypt Vision 2030 is based on the principles of "comprehensive sustainable development" and "balanced regional development". Figure 1.

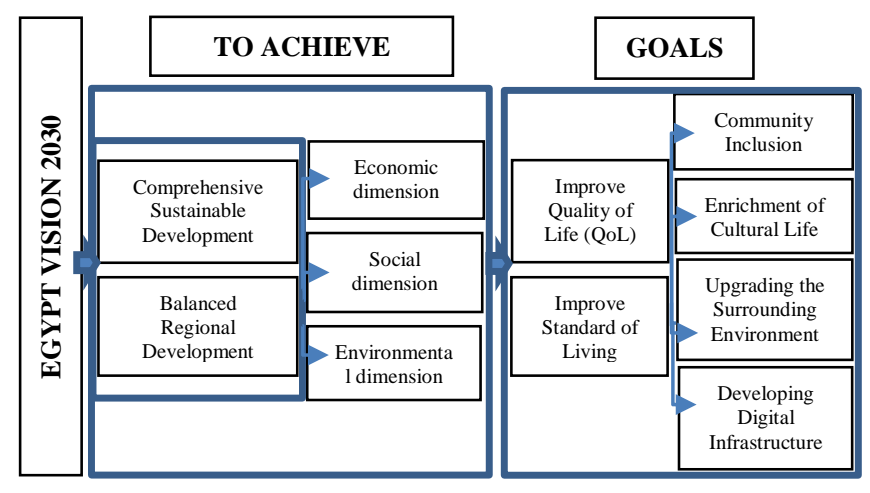

Figure1. Egypt's Vision 2030 - (Source: Researcher)

It reflects the three dimensions of sustainable development: the economic dimension, the social dimension, and the environmental dimension. Egypt's vision has a set of goals; the goal of the state plan is to improve the quality of life of Egyptian citizens and improve their standard of living through an integrated development system. The government works on foundations of justice and equity, in addition to adopting an efficient and effective integrated system of social protection based off community inclusion, enrichment of cultural life, upgrading the surrounding environment and civilized appearance, and developing digital infrastructure (GIA, 2020).

\section{Greater Cairo Region Road Networks}

In the early 1960s, the Egyptian government reversed the 
model of expanding the tram and bus network by canceling small parts of the tram network and removing the trolleybus that was passing through the heart of Cairo. Removing tram lines in favor of road expansion projects and the lack of investment in public transport buses has been a reality in Cairo. Even though in the nineties, supplying an enormous part of Greater Cairo Region by underground with 3 phases, a large part of Cairo's neighborhoods has been awaiting the various underground stages to extend to them. The bus network could not handle the volume of passengers traveling to it. It led to dissatisfaction with public transport, which made it a worse option and encouraged those able to own and use private cars on their daily trips. It created an additional traffic burden on the roads, in turn, negatively affected the road networks, especially when there are missing bus lanes on the main road. The state's general plans included rehabilitating roads to solve the traffic problems and connect new cities on the outskirts of the Greater Cairo Region (WRI, 2015).

\section{D.Human Needs and Satisfaction}

According to the human needs and satisfaction approach, an individual achieves a certain level of QoL based upon the level to which they meet their basic needs. Maslow's theory (1954) sets the foundation number of basic needs that must have met such as the need for food, safety, love, and selfesteem (Lester, 1983). Arndt (1981) suggests human needs to categorize into physical needs, social needs, and Selfactualization needs. He suggests a conceptual model of the processes determining $\mathrm{QoL}$ as a final fulfillment of individuals' goal (Arndt, 1981). According to Allardt (1993), human basic needs are having loving and being needs; it defines being needs as the needs for integration of a human into their community (Allardt, 1993).

Usually, life satisfaction measured based on an individual's evaluation of the different aspects in their life domain which meet their needs such as family relationship, financial life, and social life, according to life domains are important to them (Campbell, 1976). Human satisfaction versus different dimensions of quality of life, such as social and economic aspects.

\section{E. Quality of Life (QoL).}

One of Egypt's vision 2030 goals. The government wants to achieve a higher quality of life through large national projects that improve the Egyptians' lives, one of them being rehabilitating road networks. So, we explain several definitions listed for these concepts, for example:

- In the English dictionary, quality of life is the level of satisfaction and comfort that a person or group enjoys.

- "The degree to which a person enjoys the important possibilities of his/her life" (Hancock, 2000).

- "A feeling of wellbeing, fulfillment or satisfaction resulting from factors in the external environments" (Swain, 2002).

- Quality of life, the degree to which an individual is healthy, comfortable, and able to take part in or enjoy life events (Jenkinson, 2020). Quality of Life is rather subjective, whereas one person may define quality of life according to wealth or satisfaction with life, but another may define it in terms of capabilities.

- The World Health Organization defines quality of life (QOL) as individuals' perception of their position in life in the culture's context and value systems in which they live, and in relation to their goals, expectations, standards, and concerns (WHOQOL, 1996).

- It is a broad-ranging concept affected by the person's physical health, psychological state, personal beliefs, social relationships, and their relationship to salient features of their environment (WHOQOL, 2021).

- European Union defined (8+1) dimensions/domains based on academic research and several initiatives; the following $8+1$ dimensions/domains that have defined as an overarching framework for the measurement of well-being; these dimensions are Material living conditions (income, consumption ....), productive or main activity, health, education, leisure and social interactions, economic security and physical safety, governance and basic rights, natural and living environment and overall experience of life (Eurostat, 2020).

QoL is a multi-disciplinary concept that has a multidimensional aspect. Each dimension has a lot of indicators. Quality-of-life indicators includes the quantitative and the qualitative criteria based on the individual and community levels. The qualitative criteria based on the individual level is satisfaction about life, feeling happy etc., whereas on the level of the community; the ability to take part and to have affected the amount of correlation between the individual and society (Jones, 2002).

\section{F. Urban Quality of Life ( $Q o L)$}

Improving the quality of life in cities means how to achieve the human satisfaction with different urban attributes such as transportation, quality of public spaces, recreational opportunities, land use patterns or population and building densities. Urban quality of life is a reticular relationship between various dimensions which relate to places and communities such as social, economic, political, environmental, safety, mobility etc. Obviously, we understand the urban quality of life through the relationship between those dimensions (Serag El-Din,2013). From the literature review, it can deduce the eight crucial dimensions which contribute to realize the urban quality of life: social urban QoL; psychological urban QoL; economical urban QoL; Safety \& security urban QoL; physical urban QoL; mobility urban QoL; political urban QoL and environmental urban QoL. Table 1. 
TABLE 1

DIMENSION OF URBAN QUALITY OF LIFE (SOURCE: RESEARCHER)

\begin{tabular}{|c|c|}
\hline \multicolumn{2}{|c|}{ Dimensions of urban quality of life } \\
\hline $\begin{array}{l}\text { Social urban } \\
\text { QoL }\end{array}$ & $\begin{array}{l}\text { The social dimension of the neighborhood, the } \\
\text { people interaction, individual choices, and the } \\
\text { participation of citizens. }\end{array}$ \\
\hline $\begin{array}{l}\text { Psychological } \\
\text { urban QoL }\end{array}$ & $\begin{array}{l}\text { The feeling of individuals toward their } \\
\text { neighborhood, such as the identity of the place. }\end{array}$ \\
\hline $\begin{array}{l}\text { Economical } \\
\text { urban QoL }\end{array}$ & $\begin{array}{l}\text { All elements to characterize the neighborhood as } \\
\text { a place of economic activities as well as } \\
\text { considering property values. }\end{array}$ \\
\hline $\begin{array}{c}\text { Safety \& security } \\
\text { urban QoL }\end{array}$ & $\begin{array}{c}\text { Expansion of crimes, car accidents, riots, and } \\
\text { violence. }\end{array}$ \\
\hline $\begin{array}{c}\text { Physical urban } \\
\text { QoL }\end{array}$ & $\begin{array}{c}\text { To facilitate urban fabric, land use, services, } \\
\text { facilities, and infrastructure. }\end{array}$ \\
\hline $\begin{array}{l}\text { Mobility urban } \\
\text { QoL }\end{array}$ & $\begin{array}{l}\text { Discussion of the accessibility, traffic, and } \\
\text { transportation issues. }\end{array}$ \\
\hline $\begin{array}{l}\text { Political urban } \\
\text { QoL }\end{array}$ & $\begin{array}{l}\text { The city policies which support the concept of } \\
\text { urban quality of life and the extent to which } \\
\text { these policies are implemented }\end{array}$ \\
\hline $\begin{array}{c}\text { Environmental } \\
\text { urban QoL }\end{array}$ & $\begin{array}{l}\text { Natural and physical environments are } \\
\text { considered to protect the neighborhood from } \\
\text { main sources of pollution. }\end{array}$ \\
\hline
\end{tabular}

The concept of quality of life is considered the most comprehensive because it includes a set of dimensions that define the different aspects of life, such as economic, environmental, and social etc. While the concept of urban quality of life includes dimensions related to the elements of urbanization that achieves the QoL for community individuals. Each dimension of the quality of life in its broadest and general sense can correspond to more than one dimension of urban quality of life. For example, social interaction may correspond to social urban QoL and psychological urban QoL. Table 2.

\section{G.Urban Physical Dimensions to Perceive Urban Spaces}

Lynch argued that Legible places -Legibility- allows people to form a clear and accurate image of a place which helps the users to orientate themselves, and influenced by five items: landmarks, edges, districts, nodes, and paths. So, there are five physical dimensions to perceive urban spaces, paths, edges, district, nodes and landmarks (Lynch, 1960):

1) Paths are the channels along which individuals normally, occasionally, or potentially move. It may be streets, walkways, transit lines, canals, or railroads. Individuals observe the city or neighborhood while moving through it. There are several characteristics that must have followed in urban design to emphasize this dimension, such as.

1. Confirmation of the clarity of beginnings and ends.

2. The graduation of paths in importance.

3. Confirmation on directional quality.

4. Dynamic shaping of paths (different feelings and experiences during movement and viewing).

5. Ensuring the continuity (colors, plants, architecture details, character, function, street names, hierarchical or topographic).

6. Melody (Visual elements organization/ landmarks/ contrast between different forms and spaces).

2) Edges are the linear elements not used or considered as paths by the individuals. The edges are the boundaries between the blocks, or the line separating two areas with a difference in the topography, such as the defensive walls of ancient cities, the line of communication between land and water and rapid lines of movement. There are distinct edges (Youssef, 1983):

Fragmentary Edges, such as the edges of blocks that appear separately. Overhead Edges, such as elevated railways and bridges. Visible Edge, such as a water border. There are several characteristics that must have followed in urban design to emphasize this dimension, such as.

1- Clarity \& Continuity.

2- Edges Confirmation (easy to see or identify).

3- The presence of highways on the borders.

4- Use of different structural material or architecture solutions.

5- Use of different landscape elements or architecture. Solutions.

6- Designing the edges to give orientation characteristics.

7- The presence of fragmentary edges.

8- The presence of overhead edges (bridges, ...)

3) Districts are the medium-to-large sections of the city which are recognizable as having some common, identifying character. Usually identifiable from the inside, we also use them for exterior reference if visible from the outside. Sometimes there is a confusion between the district and the node, but it is possible to distinguish between them spatially, as the neighborhood needs a longer time to realize it. There are several characteristics that must have followed in urban design to emphasize this dimension, such as.

1. Continuity of common characteristics.

2. Continuity \& Harmony.

3. Uniform spatial formation (topography/ colors / building materials /urban fabric /plants /skyline).

4) Nodes are points, the strategic spots in a city into which an individual can enter. They are primarily junctions, places of a break in transportation, a crossing or convergence of paths. Or the nodes may be simply concentrations, as a street-corner hangout or an enclosed square. There are several characteristics that must be followed in urban design to emphasize this dimension, such as:

1. Confirmation of the clarity and continuity of the walls.

2. The presence of attractive elements.

3. Considering the simplicity of general formation.

4. Ease of cognitive communication between nodes and paths.

5. Connection of nodes by clearly paths.

5) Landmarks are distant ones, typically seen from many angles and distances or over the tops of smaller elements. They may be within the city or at such a distance that for all practical purposes they symbolize a constant direction. Such It isolates such towers, golden domes, great hills. There are several characteristics that must be followed in urban design to emphasize this dimension, such as.

1- Presence of singularity \& unity.

2- Contrast in terms of urban context.

3- Clarity of general form.

4- Distinction in design or general detail.

5- Ease in cognition and vision.

6- Ensuring its belonging to the surrounding context. 
7- Integration with another landmark.

TABLE 2

THE RELATION BETWEEN THE DIMENSIONS OF QUALITY OF LIFE (QOL) AND URBAN QUALITY OF LIFE (SOURCE: RESEARCHER)

\begin{tabular}{|c|c|c|c|c|c|}
\hline \multicolumn{4}{|c|}{$\begin{array}{c}\text { EUROPEAN UNION } \\
\text { (Dimensions \& Indicators of QoL) }(8+1)\end{array}$} & \multirow{2}{*}{ 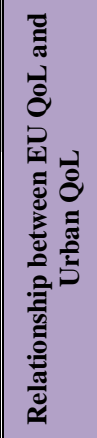 } & \multirow[b]{2}{*}{$\begin{array}{l}\text { URBAN QoL } \\
\text { DIMENSIONS }\end{array}$} \\
\hline Dimensions of $(Q \circ L)$ & Indicators & 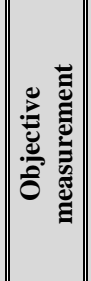 & 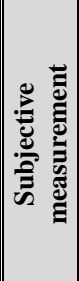 & & \\
\hline \multirow[t]{2}{*}{ Material living condition } & -Income & $\bullet$ & & \multirow{5}{*}{$\longrightarrow$} & \multirow[t]{2}{*}{ Social urban QoL } \\
\hline & -Consumption & $\bullet$ & & & \\
\hline \multirow[t]{4}{*}{ Productive or main activity } & -Quantity of employment & $\bullet$ & & & \\
\hline & -Quality of employment & $\bullet$ & $\bullet$ & & \multirow{3}{*}{$\begin{array}{l}\text { Psychological } \\
\text { urban QoL }\end{array}$} \\
\hline & -Main reason for economic inactivity & $\bullet$ & & & \\
\hline & -Unpaid work & & o & & \\
\hline \multirow[t]{3}{*}{ Health } & -Health outcomes indicators & $\bullet$ & $\bullet$ & & \multirow[t]{3}{*}{$\begin{array}{c}\text { Economical urban } \\
\text { QoL }\end{array}$} \\
\hline & $\begin{array}{l}\text {-Determinants (healthy and unhealthy } \\
\text { behaviors') }\end{array}$ & $\bullet$ & & & \\
\hline & -Access to healthcare & $\bullet$ & $\bullet$ & & \\
\hline \multirow[t]{3}{*}{ Education } & -Competences and skills & $\bullet$ & $\bullet$ & & \multirow{3}{*}{$\begin{array}{l}\text { Safety \& security } \\
\text { urban QoL }\end{array}$} \\
\hline & -Lifelong learning & $\bullet$ & & & \\
\hline & -Opportunities for education & $\bullet$ & & & \\
\hline \multirow[t]{2}{*}{ Leisure and social interaction } & -Leisure & $\bullet$ & $\bullet$ & & \multirow{3}{*}{$\begin{array}{l}\text { Physical urban } \\
\text { QoL }\end{array}$} \\
\hline & -Social interaction & $\bullet$ & $\bullet$ & & \\
\hline \multirow{2}{*}{$\begin{array}{c}\text { Economic security and physical } \\
\text { safety }\end{array}$} & -Economic security & $\bullet$ & & & \\
\hline & -Physical safety & $\bullet$ & $\bullet$ & & \multirow[t]{3}{*}{$\begin{array}{l}\text { Mobility urban } \\
\text { QoL }\end{array}$} \\
\hline \multirow[t]{3}{*}{ Governance and basic rights } & -Institutions and public services & & $\bullet$ & & \\
\hline & $\begin{array}{l}\text {-Discrimination and equal } \\
\text { opportunities }\end{array}$ & $\bullet$ & & & \\
\hline & -Active citizenship & & O & & \multirow{3}{*}{$\begin{array}{l}\text { Political urban } \\
\text { QoL }\end{array}$} \\
\hline \multirow[t]{3}{*}{ Nature and living environment } & -Pollution & $\bullet$ & $\bullet$ & & \\
\hline & -Access to green and recreational spaces & & $\bullet$ & & \\
\hline & -Landscape and built environment & & $\bullet$ & & \multirow[t]{3}{*}{$\begin{array}{c}\text { Environmental } \\
\text { urban QoL }\end{array}$} \\
\hline \multirow[t]{2}{*}{ Overall experience of life } & -Life satisfaction & & $\bullet$ & & \\
\hline & -Meaning and purpose of life & & $\bullet$ & & \\
\hline
\end{tabular}

H.The Relationship between Physical Dimensions of Perceiving Urban Spaces and Urban QoL Dimensions

There is a matrix relationship between physical dimensions of perceiving urban spaces and the dimensions of urban QoL. This matrix shows how each characteristic of physical dimensions of urban space affected different dimensions of urban QoL Table 3. First, each element has a different effect on urban quality of life, but paths and their characteristics made the biggest effect among all physical elements of urban spaces. Second, people can see and perceive the rest of the elements

through moving within the paths. Accordingly, The rehabilitation of the road network affects individuals' 
perception of the urban environment around them, whether positively or negatively.

TABLE 3.

THE RELATIONSHIP BETWEEN PHYSICAL ELEMENTS OF PERCEIVING URBAN SPACES AND URBAN QUALITY OF LIFE (QOL) (SOURCE: RESEARCHER)

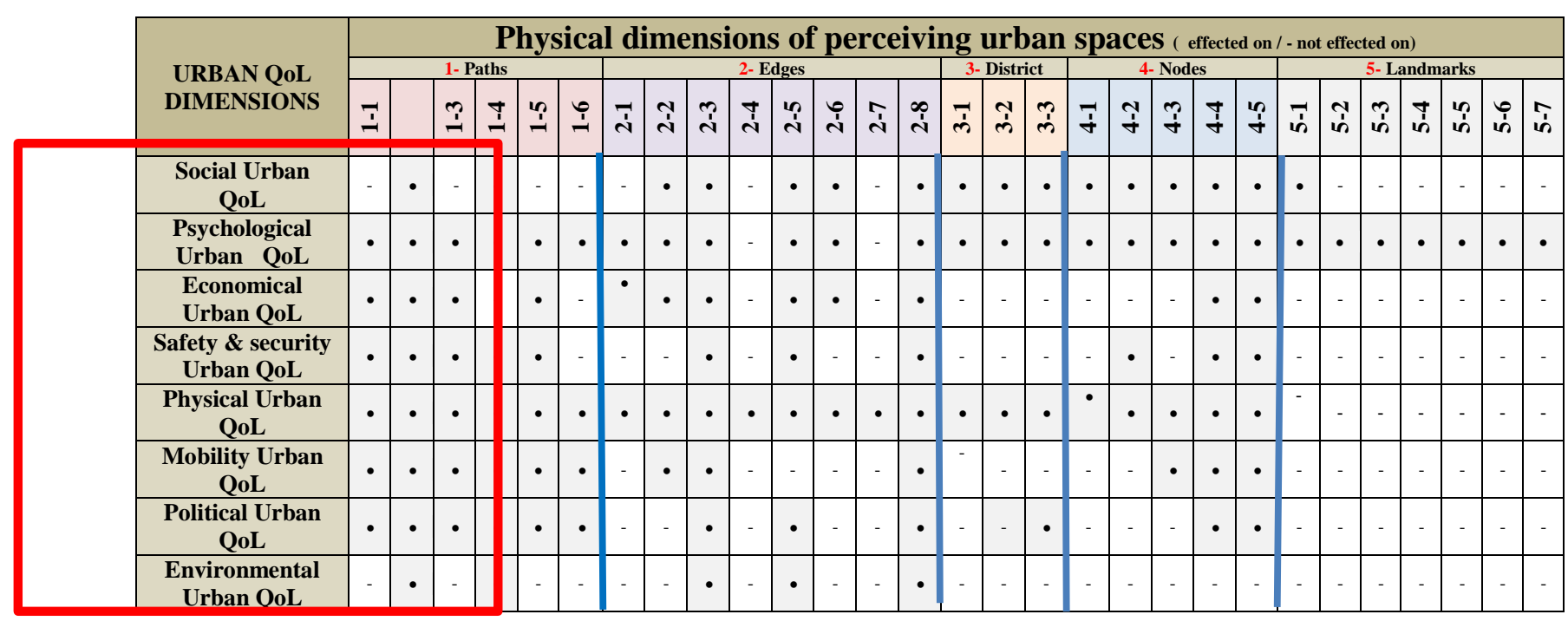

From, Table 3, by studying the relationship between the physical elements that perceive urban spaces and the range of their impact on the quality of life it was found that the characteristics and features of the paths are the major influence on the quality of urban life. Therefore, the importance of the research paper is studying the impact of road rehabilitation on the quality of life in general, and urban QoL especially.

\section{Non-physical urban dimensions to perceive urban spaces}

Lynch argued that Legible places -Legibility- allows people to form a clear and accurate image of a place by five items (landmarks, edges, districts, nodes, and paths). Meanwhile, consider this image of a place as the character of the place or the physical part of identity.

Through the literature review, we have shown that perceiving urban space can depend on non-physical dimensions. Firstly, one of these forms is Livability, one of important forms to measure urban quality of life (Ana, 2014), it has six Livability Principles, some of them have a direct contact with paths (road networks) such as;

- provide more transportation choices (i.e., Develop safe, reliable, and affordable transportation choices. Improve air quality, reduce greenhouse gas emissions, and promote public health).

- Value communities \& neighborhoods (i.e., making places that we enjoy being in, such as great walking paths, parks, plazas, and community gardens. Bringing these amenities into communities contributes to contributes to the overall well-being of residents and visitors) (Eden Area, 2013).

- Public safety (i.e., Safety is characterized by elements that support and enhance a public safety presence through collaborative efforts that promote safe routes throughout the neighborhood).
- Accessibility (i.e., to parks \& open space is characterized by safe, clean, accessible paths). (Eden Area, 2013) (Walk Score, 2020). Each of these principals has many characteristics or features related to road networks to achieve urban quality of life.

Secondly, place attachment, we characterize it as the development of an affective bond or link between people or individuals and particular places (Hidalgo, 2000). We also express it in the functional bonding between people and places, people's dimension of place attachment refers to its individually or collectively determined meanings. The psychological dimension includes the affective, cognitive, and behavioral components of attachment. The place dimension emphasizes the place characteristics of attachment, including spatial level, specificity, and physical elements. Paths are considered one of essential physical to achieve place attachment between individuals and their urban spaces.

Thirdly, Place identity refers to the identification of emotions and feelings to a specific place. Meanwhile, it related to people's meanings and perceptions of their environment (Ujang, 2010).

We define place identity as a part of an individual personal identity; it is a process in which people belonging to a specific place emerge through interaction with places (Hidalgo, 2000). All these physical, non-physical dimensions, sub-dimensions and indicators of the road networks rehabilitation are shown in Table 4.

\section{APPLIED STUDY}

Through a case study on the "Heliopolis" neighborhood, one of Egypt's inherent neighborhoods within the Greater Cairo Region, the history of the neighborhood of residence recognized, and the road networks inside have been rehabilitated over the past few years. The applied study 
depends on interviews with neighborhood residents to conduct their views on the physical/ non-physical forms of urban spaces to perceive paths, before and after road networks rehabilitation. It also conducted an electronic questionnaire for the residents of "Heliopolis" neighborhood to know the effect of the rehabilitation of road networks on the urban quality of life. Residents' study sample done among their advantages:

- Diversity between men and women.

- Residents of the neighborhood for at least the last three decades.

- We calculated percentages for the total opinions about the level of satisfaction before and after the rehabilitation.

\section{A. History of "Heliopolis" Neighborhood}

In 1905, Baron Empain was established the Cairo Electric Railways and Heliopolis Oases Company, which bought extensive areas of desert some distance northeast of Cairo from the British government. He built the new town of Heliopolis, which was fifteen kilometers from the center of Cairo. It was designed as a "city of luxury", for specific social top classes. In addition, there was housing for workers.

Heliopolis originally filled primarily with aristocratic Egyptians, as well as some European nationals. On the contrary to other suburbs around Cairo at the beginning of 20th century. After the 1952, it became home to much of Cairo's educated middle class. As Cairo has expanded, Heliopolis is now well inside the city because of the enormous growth in Egypt population (Akaar Map, 2020).

\section{B. "Heliopolis" Neighborhood NOW}

Since the eighties, urban expansions and new cities spread east of Cairo on both sides of the Suez Road, which gave these new cities a strategic location between the capital and the port of Suez. These cities also granted access to cheap land with the aim of real estate investment, which led to an increase in traffic flow on this road (Elkateb, 2020).

Now, the growth of many new cities in the suburb of Cairo established, such as New Cairo City, Rehab, Madinaty, El Shorouk City, Badr city, New Heliopolis city and the New Administrative Capital. These cities are similar because Suez Road is the main exit to them or one of its exits, which is the basis for the smooth movement from this road into Cairo.

Recently the Egyptian government is rehabilitating roads to accommodate the movement of vehicles from the new cities east of Cairo to easily integrate them into Cairo itself. In the same context, the Egyptian government has developed the road networks within the neighborhoods (Heliopolis and Nasr City neighborhood) in which the vehicles of Suez Road could flow.

\section{Rehabilitation of Road Networks in "Heliopolis"}

Recently in 2019, the government planned and executed the development the Heliopolis area included :

First, road networks expanding in the neighborhood at the expense of metro lines and reducing the sidewalks between the road or sidewalks. Second, implement of six bridges (Elkateb,
2020); including Bridge at the intersection of Al-Mirghani with Abu Bakr Al-Siddiq Street, the bridge at the intersection of Al-Mirghani with the Square of Sabaa Emarat, the bridge at the intersection of El Nozha Street with Salah Salem above El Galaa Bridge, the bridge at the intersection of Abu Bakr AlSiddiq Street with Othman bin Affan and the bridge of Mahkama square Figure 2.

But the sixth bridge is in "Heliopolis", at Gesr Al Suez street in Mansheyat Al Bakri Area, to serve traffic movement on the boundaries axes of the neighborhood.

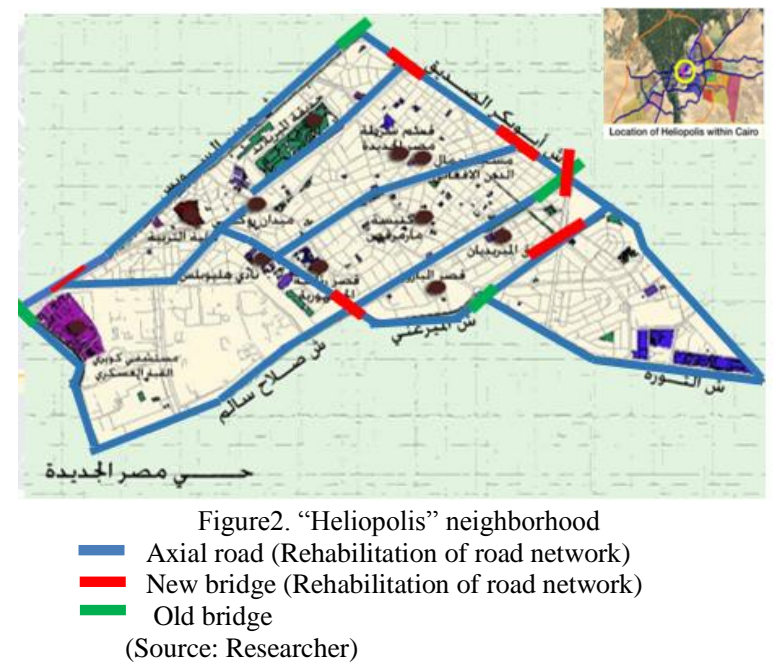

\section{D.Interview with neighborhood residents}

Interview with neighborhood residents have measured residents' satisfaction on their urban QoL. And analyzed the physical/ non-physical dimensions of urban spaces to perceive paths before and after the rehabilitation of the road networks.

The study sample in the interviews numbered up to 20 neighborhood residents', Table 4.

\section{E. The impact of Rehabilitation of road networks on urban QoL (Interview with resident's neighborhood)}

The rehabilitation of the road networks inside "Heliopolis" neighborhood is an important event that has been introduced to the area since its establishment in the early last century. By interviewing the concept of urban quality of life among the neighborhood residents' before and after rehabilitation, who lived in it before and after the rehabilitation:

\section{Social urban QoL}

Before rehabilitation:

$>$ The neighborhood residents practiced social activities through nodes, squares, gathering places and shopping areas, such as "Salah El Din" Square.

$>$ The existence of different open social spaces, such as the "Elgaba Sports Club" and "Mereland Park", which served as the lung of "Heliopolis" neighborhood.

$>$ Heliopolis is one of the inherent neighborhoods in Cairo, which there are many social activities, and none profit organizations that specialize in serving the neighborhood residents. 
TABLE 4

RESIDENTS' SATISFACTION BEFORE AND AFTER ROAD REHABILITATION WITH ROAD NETWORKS REHABILITATION DIMENSIONS (PHYSICAL/NON-PHYSICAL) (SOURCE: RESEARCHER)

\begin{tabular}{|c|c|c|c|c|c|c|}
\hline \multicolumn{4}{|c|}{ DIMENSIONS OF ROAD NETWORKS REHABILITATION } & \multicolumn{3}{|c|}{ BEFORE \& AFTER REHABILITATION } \\
\hline \multicolumn{2}{|c|}{ Dimensions } & $\begin{array}{c}\text { Sub } \\
\text { Dimensions }\end{array}$ & $\begin{array}{c}\text { Indicators } \\
\text { Characteristics (Features) }\end{array}$ & Bef & Afte & Discussion \\
\hline \multirow{6}{*}{. } & \multirow{6}{*}{ 尝 } & \multirow[t]{6}{*}{ 1-1 Paths } & $\begin{array}{l}\text { 1.A. Confirmation of the clarity of beginnings and } \\
\text { ends }\end{array}$ & $\begin{array}{l}95 \\
\%\end{array}$ & $10 \%$ & \multirow{6}{*}{$\begin{array}{l}\text { - A lot of express roads were become } \\
\text { uncertain or obvious endings (upper bridges } \\
\text {-no road intersections). } \\
\text { - The presence of six express roads (An } \\
\text { arterial pathway) inside neighborhoods. } \\
\text { - Dynamic shaping has been observed of } \\
\text { internal paths but new express roads are } \\
\text { penetrating the neighborhood directly. } \\
\text { - Although the physical forms did not have } \\
\text { a big change, but the perception of } \\
\text { neighborhood residents have s hug change } \\
\text { to their images. }\end{array}$} \\
\hline & & & 1.B. The graduation of paths in importance & $\begin{array}{l}98 \\
\%\end{array}$ & $25 \%$ & \\
\hline & & & 1.C. Confirmation on directional quality & $\begin{array}{l}98 \\
\%\end{array}$ & $95 \%$ & \\
\hline & & & $\begin{array}{c}\text { 1.D. Dynamic shaping of paths (generation of } \\
\text { different feelings and experiences during movement } \\
\text { and viewing) }\end{array}$ & $\begin{array}{l}90 \\
\%\end{array}$ & $90 \%$ & \\
\hline & & & $\begin{array}{l}\text { 1.E. Ensuring the continuity (colours, plants, arch. } \\
\text { details, Character, function, street names, } \\
\text { hierarchical or topographic) }\end{array}$ & $\begin{array}{l}90 \\
\%\end{array}$ & $90 \%$ & \\
\hline & & & $\begin{array}{l}\text { 1.F. Melody (Visual elements organization } \\
\text { /landmarks / contrast between different forms and } \\
\text { spaces }\end{array}$ & $\begin{array}{l}95 \\
\%\end{array}$ & $50 \%$ & \\
\hline \multirow{21}{*}{ 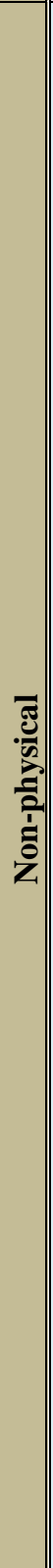 } & \multirow{21}{*}{ 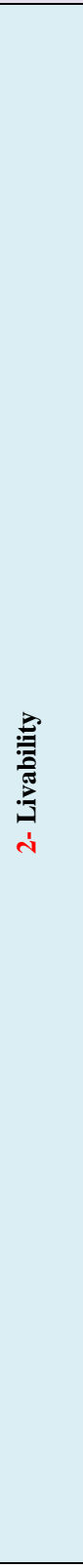 } & \multirow{13}{*}{$\begin{array}{l}\text { 2-1 Provide } \\
\text { More } \\
\text { Transportatio } \\
\text { n Choices } \\
\text { making places } \\
\text { that we enjoy } \\
\text { being in, such } \\
\text { as great } \\
\text { walking paths, } \\
\text { parks, plazas, } \\
\text { and community } \\
\text { gardens. } \\
\text { Bringing these } \\
\text { amenities into } \\
\text { communities } \\
\text { contributes to } \\
\text { contributes to } \\
\text { the overall } \\
\text { well-being of } \\
\text { residents and } \\
\text { visitors }\end{array}$} & 2.A. Public transportation that includes bus, bikes & $\begin{array}{l}50 \\
\%\end{array}$ & $50 \%$ & \multirow{13}{*}{$\begin{array}{l}\text { - All bus routes were changed due to road } \\
\text { networks rehabilitation. Because express } \\
\text { roads should not have bus routes to keep its } \\
\text { traffic fluency. } \\
\text { - Reduce energy consumption, dependence } \\
\text { on walkability and enhancing of getting } \\
\text { around, it is not applicable after road } \\
\text { rehabilitation. } \\
\text { - Walkability and daily activities were } \\
\text { decreased due to difficulty of cross new } \\
\text { road networks, no pedestrian transit and } \\
\text { speed limit } 60 \mathrm{~km} / \mathrm{h} \text {. } \\
\text { - Internal roads was preserved their } \\
\text { appearance as a n inherent neighborhood. } \\
\text { - Paths must be promoted a well } \\
\text { maintenance, open spaces and clean } \\
\text { environment to reach residents' satisfaction. }\end{array}$} \\
\hline & & & 2.B. Policy more responsive, resilient, and flexible. & $\begin{array}{l}90 \\
\%\end{array}$ & $30 \%$ & \\
\hline & & & $\begin{array}{l}\text { 2.C. Transportation alternatives at state legislative } \\
\text { level }\end{array}$ & $\begin{array}{l}80 \\
\%\end{array}$ & $80 \%$ & \\
\hline & & & $\begin{array}{l}\text { 2.D. Transportation options via newsletters, media } \\
\text { reports, etc. }\end{array}$ & $0 \%$ & $0 \%$ & \\
\hline & & & 2.E. Transportation from public or private transit & $\begin{array}{l}80 \\
\%\end{array}$ & $80 \%$ & \\
\hline & & & $\begin{array}{l}\text { 2.F. Give all communities in the region a voice in } \\
\text { transportation planning }\end{array}$ & $0 \%$ & $0 \%$ & \\
\hline & & & 2.G. Explore bus routes in key areas. & $0 \%$ & $0 \%$ & \\
\hline & & & $\begin{array}{l}\text { 2.H. Integrate transportation planning into economic } \\
\text { development strategies. }\end{array}$ & $\begin{array}{l}80 \\
\%\end{array}$ & $60 \%$ & \\
\hline & & & $\begin{array}{l}\text { 2.I. Increase bike lanes in coordination with the bus } \\
\text { stops. }\end{array}$ & $0 \%$ & $0 \%$ & \\
\hline & & & 2.J. Encourage better transit schedules & $\begin{array}{l}90 \\
\%\end{array}$ & $10 \%$ & \\
\hline & & & 2.K. Affordable methods for moving people around & $\begin{array}{l}95 \\
\%\end{array}$ & $10 \%$ & \\
\hline & & & 2.L. Walkability and enhancing of getting around & $\begin{array}{l}95 \\
\%\end{array}$ & $10 \%$ & \\
\hline & & & $\begin{array}{l}\text { 2.M. Paths are characterized by signage, public art, } \\
\text { agricultural greenbelts }\end{array}$ & $\begin{array}{l}90 \\
\%\end{array}$ & $10 \%$ & \\
\hline & & \multirow{4}{*}{$\begin{array}{c}\text { 2-2 Value } \\
\text { Communities } \\
\& \\
\text { Neighborhoods }\end{array}$} & $\begin{array}{l}\text { 2.N. Funding for regular maintenance of parks, } \\
\text { plazas, open spaces, etc on paths. }\end{array}$ & $\begin{array}{l}80 \\
\%\end{array}$ & $80 \%$ & \multirow{4}{*}{$\begin{array}{l}\text {-Road networks rehabilitation should } \\
\text { maintain heritage of neighborhood to avoid } \\
\text { convert it into slum area. } \\
\text { - Making places that we enjoy being in } \\
\text { (walking paths, parks, plazas...) are } \\
\text { changed after rehabilitation, it is depends on } \\
\text { recreation spaces and coffee under bridge. }\end{array}$} \\
\hline & & & $\begin{array}{l}\text { 2-O. Protect, rehabilitate, and promote historical } \\
\text { region/ paths from different aspects. }\end{array}$ & $\begin{array}{l}95 \\
\%\end{array}$ & $15 \%$ & \\
\hline & & & $\begin{array}{l}\text { 2.P. Create, protect and enhance place making with } \\
\text { node/focal points. }\end{array}$ & $\begin{array}{l}90 \\
\%\end{array}$ & $50 \%$ & \\
\hline & & & $\begin{array}{l}\text { 2.Q. Prioritize environmental stewardship (pollution } \\
\text { produced by vehicles) }\end{array}$ & $\begin{array}{l}80 \\
\%\end{array}$ & $20 \%$ & \\
\hline & & \multirow{3}{*}{ 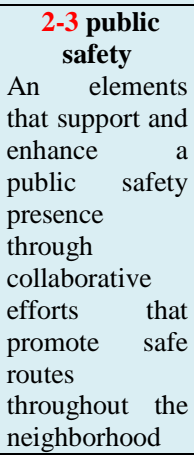 } & $\begin{array}{l}\text { 2.R. Promote safe routes throughout the } \\
\text { neighborhood for vehicles oriented }\end{array}$ & $\begin{array}{l}95 \\
\%\end{array}$ & $10 \%$ & \multirow{3}{*}{$\begin{array}{l}\text { - Residents can not feel safe and livable in } \\
\text { residential areas with express road, } \\
\text { therefore, decreasing/preventing it or } \\
\text { discouraging high speed traffic is a must. }\end{array}$} \\
\hline & & & 2.S. Safe pedestrian crossing & $\begin{array}{l}95 \\
\%\end{array}$ & $0 \%$ & \\
\hline & & & 2.T. Promote adequate lighting over the roads & $\begin{array}{l}90 \\
\%\end{array}$ & $80 \%$ & \\
\hline & & $\begin{array}{c}2-4 \\
\text { Accessibility }\end{array}$ & 2.U. Access to Parks \& Open Space & $\begin{array}{l}90 \\
\%\end{array}$ & $30 \%$ & $\begin{array}{l}\text { - Accessibility, to enter, exit or cross the } \\
\text { neighborhood is much easier on the account }\end{array}$ \\
\hline
\end{tabular}




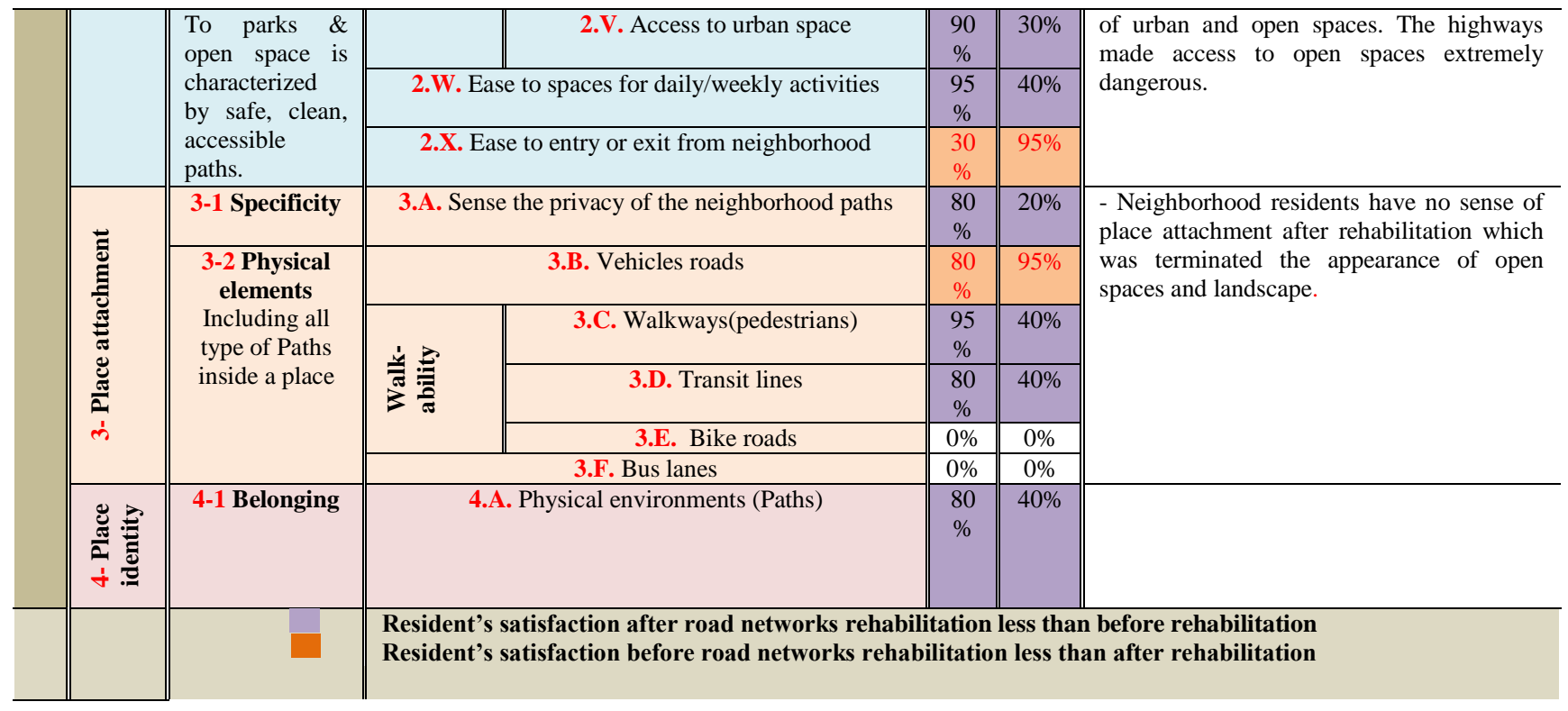

\section{After rehabilitation:}

$>$ Social activities cannot be practiced within walking distances because of the rehabilitation of roads into express roads that are difficult to cross, with the absence of pedestrian bridges.

$>$ The disappearance of squares, road intersections and nodes, hence their transformation into land roads and bridges.

$>$ Lack of green open spaces within the streets because of the expansion of the roads.

$>$ The presence of recreational and service activities, such as cafeterias under the new bridges, to provide some alternative recreational activities for the residents' neighborhood.

Psychological urban QoL

\section{Before rehabilitation:}

$>$ The original neighborhood residents feel a strong affiliation (place attachment) with the neighborhood in which they live.

$>$ Neighborhood residents feel, they belong to the place, and that it is an integral part of their personality.

$>$ The residents of the neighborhood see that they distinguished by living there because neighborhood location in the middle of large distinct neighborhoods (Nasr City, Nozha), "Heliopolis" neighborhood one of inherent place in Egypt and it is close to the main axis roads such as Suez Road, Ismailia road and the Ring Road.

After rehabilitation:

$>$ After rehabilitation, they miss their quiet neighborhood, and they feel that this neighborhood is foreign to them. They refused to move to the new cities out of their desire to stay in their privileged and quiet neighborhood.

$>$ Express roads were penetrated the neighborhood, make residents have a weak relationship with their neighborhood.

Economical urban $Q o L$

\section{Before rehabilitation:}

> "Heliopolis" neighborhood is one of the residential neighborhoods inhabited by the middle/high class, despite the presence of the Al Gamea Square area, which is the center of economic activity in the neighborhood.

$>$ The high property values are in "Heliopolis" neighborhood, on the main streets and squares.

\section{After rehabilitation:}

$>$ With the road networks rehabilitation, practicing economic activity within the neighborhood has become difficult, especially after government restriction on traffic parking.

$>$ It decreases The property values, especially those overlooking the squares or main road, after the establishment of many upper bridges at the places of intersections and new traffic regulation on parking cars.

\section{Safety \& security urban $Q o L$}

\section{Before rehabilitation}

$>$ The neighborhood was considered one of the most secure residential neighborhoods, as the speed of cars inside the neighborhood was within the speed limit, with adequate street widths for pedestrian crossing.

\section{After rehabilitation:}

$>$ With the traffic movement changes and the transformation of the main roads into express roads, it became difficult to cross the roads and thus the number of traffic accidents increased dramatically.

$>$ Since the beginning of rehabilitation of road networks, until May 2020, there have been no less than forty incidents between vehicles and pedestrians due to the lack of inefficiency of the pedestrian crossing infrastructure (Elkatib M., 2020). Cairo's traffic response was limited to monitoring vehicle speeds by radar at certain points on the axes, in addition to pedestrian crossing paths, some signs and pedestrian bridges or lanes with escalator or not. According to the report of the World Resources Institute (WRI, 2015), neighborhood design based on a connected 
and dense model, which reduces the need for vehicle driving and shortens trip lengths radically reducing the speed of vehicles to minimum speeds, i.e., less than 30 $\mathrm{km} / \mathrm{h}$. The report states that "the risk to pedestrians at a speed of $50 \mathrm{~km} / \mathrm{h}$ for vehicles is more than twice the risk in the case of $40 \mathrm{~km} / \mathrm{h}$ and more than 5 times the risk in the case of $30 \mathrm{~km} / \mathrm{h}$ " as shown in Figure 3.

\section{Physical urban QoL}

\section{Before rehabilitation:}

$>$ There were a lot of urban spaces designed by landscape elements all over the neighborhood besides "El-Gaba Sports Club" and "Mereland Park" with a large area to practice social and recreational activities.

$>$ Walkability, the major activity for residents to do daily or weekly to do their needs. Pedestrian could have a lot of fun and enjoy recreation through open spaces with different landscape elements.

\section{After rehabilitation:}

$>$ Road networks rehabilitation was decreased urban spaces to make express road through the neighborhood. All street islands and main squares have disappeared, transfer into "U" turn. Figure 4,5.

$>$ Physical urban such as open spaces, urban fabric, land use, services, facilities, and infrastructure are become unaccessible for neighborhood residents due to express road and safety reasons.

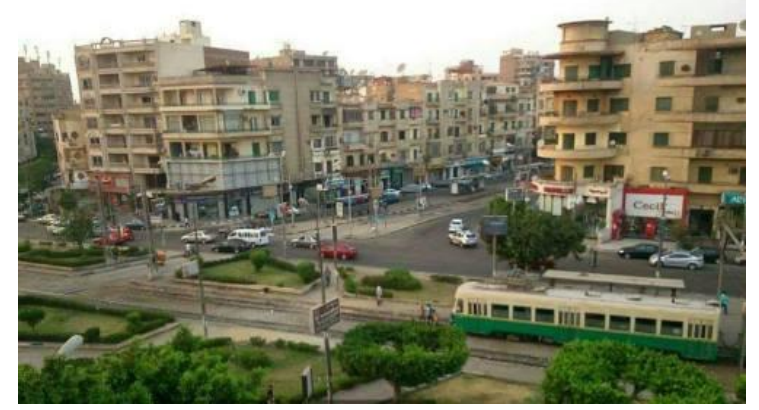

Figure 4. Saffir square (intersection of Abu Bakr Al-Siddiq Street with Othman bin Affan), 2004

Source: Page, Ana min Misr EL-Gadida, Facebok

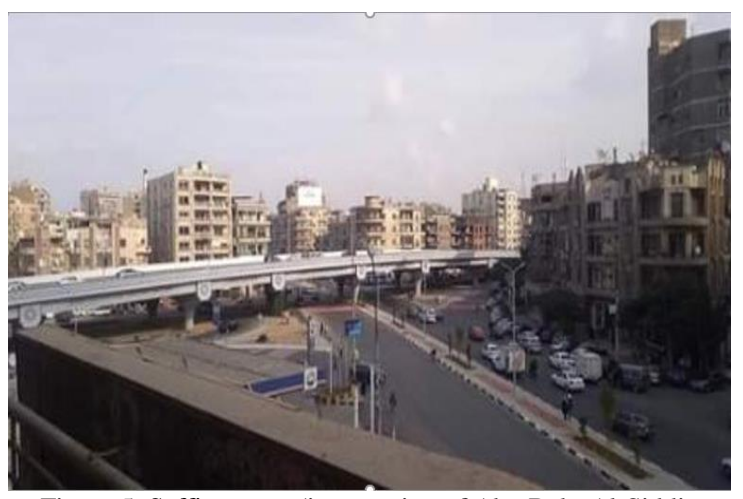

Figure 5. Saffir square (intersection of Abu Bakr Al-Siddiq Street with Othman bin Affan), 2020 Source: 18

\section{Mobility urban QoL}

\section{Before rehabilitation:}

$>$ The roads and nodes are suitable for the neighborhood, but with traffic jams on the main roads, especially during rush hours.

$>$ The presence of distinctive signs of the residential neighborhood, such as mosques, churches, and luxurious palaces characteristic of the neighborhood, which are considered attractions for residents and others.

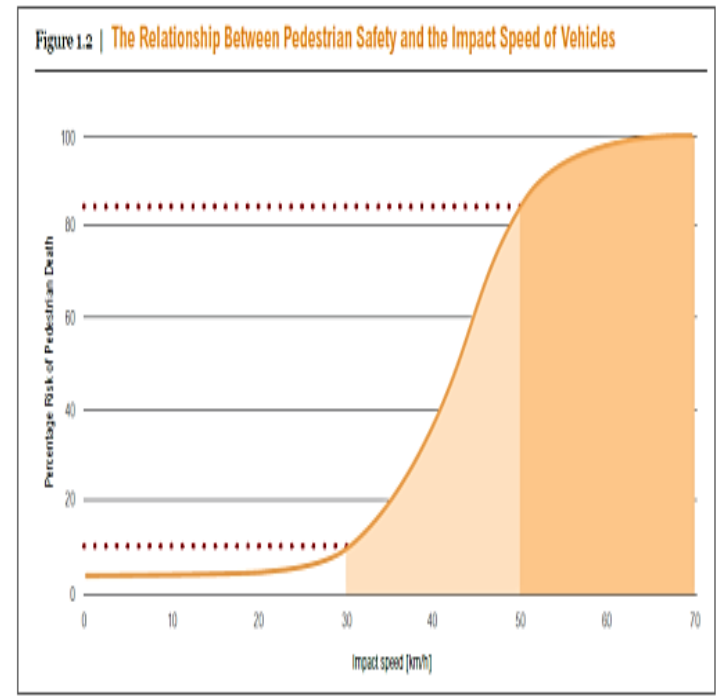

Figure 3. The relation between pedestrian safety and the impact speed of vehicles

Source: World Resources Institute (WRI), (2015)

\section{After rehabilitation:}

$>$ The penetration of the vehicle's movement of the main roads in the neighborhood at high speeds $(60 \mathrm{~km} / \mathrm{h}$ and more), the neighborhood lost a large part of the quality of its urban development, despite the ease of vehicles movement and the reduction of traffic congestion.

$>$ Accessibility, to enter, exit and cross the neighborhood, Traffic fluidity has been done.

\section{Political urban QoL}

Before rehabilitation:

$>$ Governmental policies with "Heliopolis" neighborhood over the last decades based on preserving old residential neighborhoods while working on widening roads at the expense of metro lines, which removed from many streets; the last of which was Al-Hijaz Street.

After rehabilitation:

$>$ Within the framework of the government plans to connect and integrate the new cities with the Greater Cairo region by road networks that achieve traffic fluency. The government has rehabilitation the road networks by converting them into axial roads, with the establishment of many bridges within the neighborhoods next to the Suez Road.

$>$ Forcing residents to use their cars within the neighborhood, as they will use it for purposes that did not require automatic transportation in the past, such as 
transporting children to their schools or buying basic household needs.

\section{Environmental urban $Q o L$}

\section{Before rehabilitation:}

$>$ In the last century, the Heliopolis suburb was one neighborhood in eastern Cairo, its beautiful atmosphere and wonderful trees characterized which as a neighborhood for the rich families. The "Mereland Park" was established as a place for recreation and leisure within the neighborhood.

$>$ But with time, the population and the urban area of Cairo increased. and the suburb became a crowded neighborhood among many densely populated residential neighborhoods.

$>$ Despite the expansion of the urban area, the residential neighborhood preserved its urban features and the many landscape elements.

\section{After rehabilitation:}

$>$ Now, with the neighborhood endures many traffic densities resulting from the traffic flow. The neighborhood has become more exposed than ever to environmental pollution, especially with the elimination of many landscape elements.

$F$. The impact of Rehabilitation of road networks on urban QoL (Questionnaire with "Heliopolis" neighborhood residents).

A questionnaire has been conducted with "Heliopolis" neighborhood residents to investigate the degree of resident's satisfaction on their urban quality of life. The study sample in the questionnaire are contained 30 residents

The questionnaire was done by two stages: -

First: Use (Likert-Scale) scale 1 to 5,1 is the least, 5 is the best to measure residents' satisfactions with urban QoL dimensions. The questionnaire has 13 statements, Figure 6 . Which are represented eight urban QoL, Figure 7.

Second: Use (Multiple choices) to measure residents' satisfaction with urban QoL dimensions before and after road network rehabilitation Figure 8.

\begin{tabular}{cc}
\hline \multicolumn{2}{c}{ The role of road networks to enhancement entertainment activities } \\
\hline $2-$ & The role of road networks to enhancement social activities \\
\hline $3-$ & The role of road networks to perform daily activities \\
\hline $4-$ & The role of road networks to sense of belonging \\
\hline $5-$ & The role of road networks to raise your property value \\
\hline $6-$ & The role of road networks to transportation network \\
\hline $7-$ & The role of road networks to have a lot of parking space \\
\hline 8- & The role of road networks in mobility the traffic lines \\
\hline 9- & The role of road networks to feel safe and secure \\
\hline 10- & The role of road networks to maintain landscape elements and \\
urban space \\
\hline $\begin{array}{l}\text { 11- Satisfaction with government decision to rehabilitate road } \\
\text { networks }\end{array}$ \\
\hline $\begin{array}{l}\text { 12- Satisfaction with the environmental pollution of the } \\
\text { neighborhood }\end{array}$ \\
\hline 13- Satisfaction with natural environment and open spaces. \\
\hline
\end{tabular}

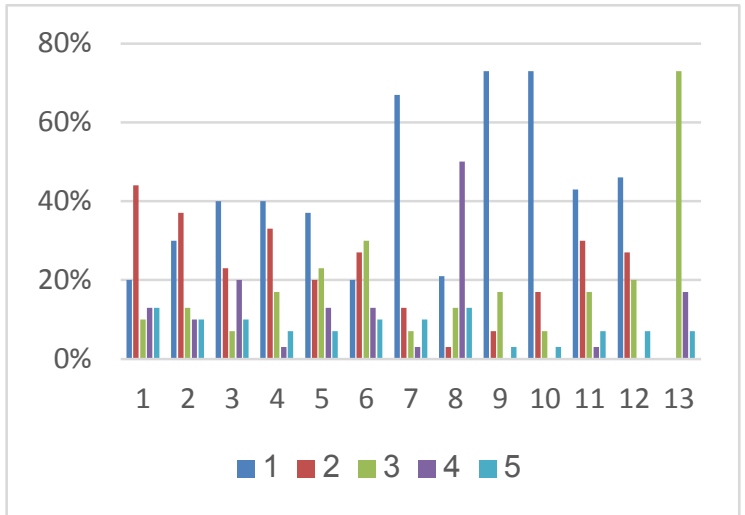

Figure 6. Residents' degree of satisfaction with urban QoL elements and dimension- (Source: By researcher)

To measure residents' satisfaction with the urban QoL dimensions, I need to simplify a questionnaire to make it easier. Therefore, I asked the questions considering the role of rehabilitation to achieve social activities, daily activities, safety, increase property value etc. These thirteen questions are represented eight dimensions of urban quality of life.

$>$ The questionnaire showed that residents' satisfaction in most of the questions are extremely low, such as in questions 9 and 10, over $70 \%$ of study sample had a satisfaction degree "1", it means that the express road through the neighborhood do not achieve safe of the residents. And rehabilitate the road networks got on account of open spaces or landscape elements. Figure 6.

$>$ Residents that had satisfaction with the mobility of traffic lines after road network rehabilitation by grade 4 or less (Question no.8). Figure 6.

$>$ Residents disagreed with government decision to rehabilitate their neighborhood in this method (Question no.11). Figure 6.

$>$ One, two or three elements of urban QoL questionnaire was represented One dimension in urban QoL. Figure 7.

For example, elements 1,2 and 3 of urban QoL represented dimension no.1(social urban QoL).

$>$ Most of the study sample, Heliopolis neighborhood residents, dissatisfied with road networks rehabilitation, over $50 \%$ of sample getting 2 or less in satisfaction grad. Figure 7.

$>$ There are three of urban $\mathrm{QoL}(4,5,8)$ have a lowest grade "1" by over $60 \%$ of study sample. These indications mean Safety \& Security urban QoL, Physical urban QoL and Environmental urban QoL are the most dimensions affected by road networks rehabilitation than other dimensions. Figure 7.

Mobility urban QoL is the most urban QoL which have much distribution satisfaction from residents (LikertScale). This result could be explained the resident's 
opinion in table 5. to that some indicators in non-physical dimensions such as "ease of entry or exit from neighborhood" have residents' satisfaction after rehabilitation. Figure 7.
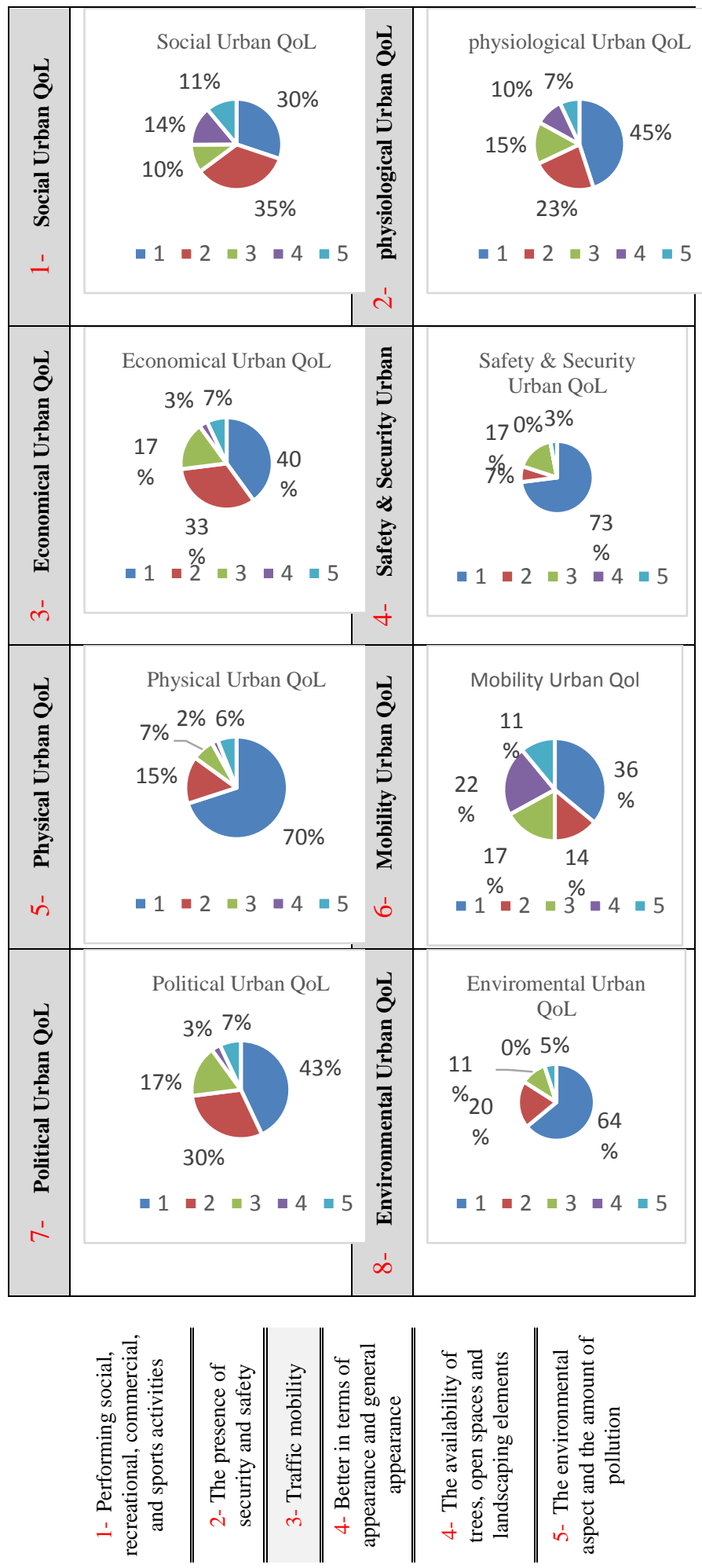

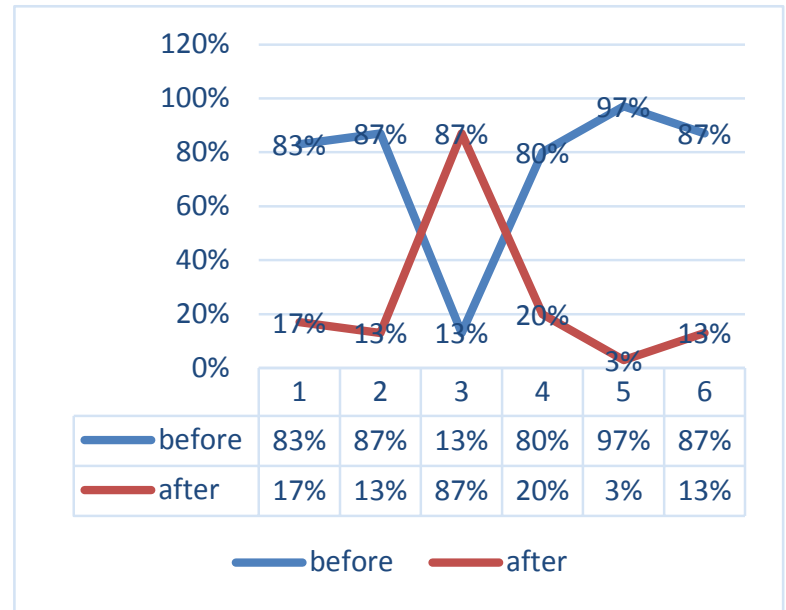

Figure 8. Residents' satisfaction with urban QoL dimensions before and after road networks rehabilitation (Source: By researcher)

This part of questionnaire was examined the residents' opinions before and after road networks rehabilitation, the investigation shown Figure 8: -

$>$ Between six questions, the resident's opinion that their neighborhood is the best before rehabilitation in five questions.

$>$ Traffic mobility is the only question that better after road networks rehabilitation.

$>$ The identical between questionnaire and interview around mobility and vehicle roads that have improved by road networks rehabilitation.

\section{DISCUSSIONS}

The first goal of the state plan is to improve the quality of life of Egyptian citizens and improve his standard of living through an integrated development system. This system includes the achievement of adaption new neighborhoods and cities with major cities and facilitating traffic and mobility. The road networks rehabilitation is one of the government processes to achieve a quality of life. In this research, the relationship between road networks rehabilitation and urban QoL was studied, as urban QoL is stage between both road network and QoL.

To study road networks, we must get information about dimensions, sub-dimensions, and indicators to measure resident's satisfaction as indicators that affect urban QoL. Physical and non-physical dimensions covered all about road rehabilitation from different aspect of life. By interviews and a questionnaire with neighborhood residents, residents refusing all aspect in urban rehabilitation illustrated the impact of rehabilitation in except, it makes it have a simple transition in or from neighborhood. They considered transformation inner road to express roads and six new bridges as a penetration to their neighborhood open space and landscape elements, decrease their belonging, increase environmental pollution and against safe and security principals. 


\section{V.CONCLUSION}

The study conclusion concluded many results in two axes, first, on the level of road networks rehabilitation, second, on the level of urban quality of life:

\section{Road networks rehabilitation}

- The study conclusion contained with a model for measuring and evaluating road rehabilitation, consisting of physical and non-material dimensions. The model consists of four main dimensions, eight sub dimensions, and a set of indicators. This model was used to evaluate "Heliopolis" neighborhood.

- Safety \& Security urban QoL, Physical urban QoL and Environmental urban QoL are the most dimensions affected by road networks rehabilitation than other dimensions.

- The state's general vision 2030 aims to achieve traffic flow through more highways and bridges and no intersections to improve the urban quality of life, but this is while neglecting the rest of the QoL dimensions such as environmental, social, economic, safe and security.

- The attempt to connect new cities and facilitate traffic movement within the mega cities must be subject to architectural and urban studies and more community participation.

- The rehabilitation of road networks must take into consideration the existing inherent neighborhoods and cities because this harm the quality of urban life within the neighborhood by eliminating open spaces and landscape elements.

- Rehabilitation of roads with expansion and bridges, is a danger to pedestrians in transit. Hence, highways should not cross residential neighborhoods, or rather, provide pedestrian bridges.

- The rehabilitation of the road networks is worked to solve the problems of traffic flow but affects other dimensions of urban quality of life, such as safety and security urban QoL and physical urban QoL.

- Dealing with the road networks rehabilitation in the inherent neighborhoods must be through preserving the existing urbanization (open spaces, landscape elements, etc.) that represents the actual value.

Urban quality of life

- The concept of urban quality of life is a comprehensive concept for all aspects of life with eight dimensions. All dimensions work together, each dimension cannot be measured separately. Any defect in one of the dimensions directly causes dissatisfaction in the other dimensions.

- The rehabilitation of road networks affects every dimension of the quality of life, and therefore this important dimension within urbanization cannot ignored, especially since the urban expansion and the development of road networks are a national goal of the state.

- we must undertake the major national projects that affect the quality of life through the community participation, as these projects are done for their own benefit.

- Continuing the follow up on implementing plans and visions of governments and countries is necessary to avoid solving the problems of the vehicle's movement and falling into harm in other non-physical aspects such as belonging and place attachment.

\section{REFERENCES}

Basic format for books:

[1] Allardt E. Ed., "Having, Loving, Being: An Alternative to the Swedish Model of Welfare Research, in M. Nussbaum and A. Sen (Eds). The Quality of Life," Oxford: Clarendon Press, P 88-94, 1993.

[2] Campbell A.C., Converse P., \& Rogers W.L., "The Quality of American Life: Perceptions, Evaluations and Satisfactions," New York: Russell Sage Foundation, 1976.

[3] Jones A., "A Guide to Doing Quality of Life Studies," University of Birmingham, 2002.

[4] Lynch K., "The Image of the City," London, England: The M.I.T. Press Massachusetts Institute of Technology Cambridge, Massachusetts, and London, England, 1960.

[5] Ujang N., "Place Attachment and Continuity of Urban Place Identity," Department of Landscape Architecture, Faculty of Design and Architecture, Universiti Putra Malaysia (UPM), pp. 61-76, 2010.

Basic format for periodicals:

[6] Arndt J., "Marketing and the Quality of Life," Journal of Economic Psychology, 1, P 283-301, 1981.

[7] Hidalgo, M. C. \& Hernández, B., "Place attachment: Conceptual and empirical questions", Journal of Environmental Psychology, Academic Press, 21(3), pp. 273-281. doi: 10.1006/jevp.2001.0221, 2001.

[8] Lester D., Hvezda J., Sullivan S., Plourde R., "Maslow's Hierarchy of Needs and Psychological Health," The Journal of General Psychology, Volume 109, Issue 1, P 83-85. doi:10.1080/00221309.1983.9711513, 1983.

[9] Serag El Din H., Shalaby A., Farouh H. E., \&Elariane S. A., "Principles of urban quality of life for a neighborhood," HBRC Journal, Volume 9, Issue 1, 86-92, 2013, Published online 2019.

[10] Scamell L.\& Gifford R., "Defining place attachment: A tripartite organizing framework," Journal of Environmental Psychology, volume 30, Issue 1, Pages 1-10, 2010

Basic format for reports:

[11] Asian Development Bank (ADB)," Road Rehabilitation Project (Loan 1455-KAZ) in Kazakhstan", Performance Evaluation Report, Operations Evaluation Department, Asian Development Bank, Dec. 2005.

[12] Hancock T., "Quality of Life Indicators and The DHC," Health Promotion Consultant, Ontario, 2000.

[13] Swain D., "Measuring Progress: Community Indicator and the Quality of Life," Jacksonville Community Council Inc, Florida, 2002.

Basic format for books / research / article (available online):

[14] Akaar Map, (2020), "Heliopolis from its inception until the development of new bridges in it," Available:

https://advice.aqarmap.com.eg/ar/heliopolis-from-inception-untilcultivation-bridges/ (accessed Dec. 08, 2020).

[15] Ana V.D., (2014), "Livability Principles," Available: https://www.vivadonaana.org/livability.php (accessed Jan. 7, 2021).

[16] EDEN AREA -LIVABILITY INITIATIVE, (2013) "Livability Principles," Available:

https://www.acgov.org/edenareavision/principles.htm (accessed Jan. 7, 2021).

[17] Elkatib M., (2020), "Bridges is Coming- How City Planners Continue to Tear Apart the Urban Fabric of Cairo's Neighborhoods by Means of Highways and Bridges," Available:

https://thesubmonitor.com/post/621629747220316160/\%D8\%A7\%D9\% 84\%D9\%83\%D8\%A8\%D8\%A7\%D8\%B1\%D9\%8A$\% \mathrm{D} 9 \% 82 \% \mathrm{D} 8 \% \mathrm{~A} 7 \% \mathrm{D} 8 \% \mathrm{AF} \% \mathrm{D} 9 \% 85 \% \mathrm{D} 8 \% \mathrm{~A} 9$ $\% \mathrm{D} 9 \% 83 \% \mathrm{D} 9 \% 8 \mathrm{~A} \% \mathrm{D} 9 \% 81-$

\%D9\%8A\%D8\%B3\%D8\%AA\%D9\%85\%D8\%B1- 
\%D9\%85\%D8\%AE\%D8\%B7\%D8\%B7\%D9\%88\%D8\%A7\%D8\%A7\%D9\%84\%D9\%85\%D8\%AF\%D9\%86-\%D9\%81\%D9\%8A\%D8\%AA\%D9\%85\%D8\%B2\%D9\%8A\%D9\%82 (accessed Dec. 25, 2020).

[18] Eurostat, (2020) "Quality of life indicators - measuring quality of life," Available:

https://ec.europa.eu/eurostat/statistics-

explained/index.php?title=Quality_of_life_indicators_-

measuring_quality_of_life\#8.2B1_dimensions_of_quality_of_life (accessed Dec. 14, 2020).

[19] Jenkinson C., (2020), "Quality of Life," Available: https://www.britannica.com/topic/quality-of-life (accessed Dec. 18, 2020).

[20] General Information Association (GIA), (2020)" Egypt Strategy for Sustainable Development (Egypt Vision 2030)" Available:

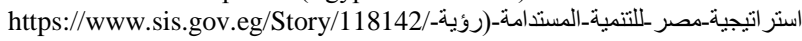
(2030- مصر??lang=ar. (accessed Dec. 08, 2020).

[21] Mohamed A.H., "Planning Values of Housing Projects in the Gaza Region and their Reflection on Future Housing Projects - A Case Study Tel Al-Hawa Housing Project, The Islamic University Journal, Series of Natural Studies and Engineering, Vol.19, No. 2, PP113-150, 2011. Available: http://www.iugaza.edu.ps/ar/periodical/ (accessed Dec. 08, 2020).

[22] Walk Score (2020), "Walkable Neighborhoods," Available: https://www.walkscore.com/walkable-neighborhoods.shtml (accessed Jan. 7, 2021).

[23] WHO (2020), "Rehabilitation," Available: https://www.who.int/news-room/fact-sheets/detail/rehabilitation (accessed Dec. 30, 2020).

[24] WHOQOL (1996) "Programme on Mental, Health World Health Organization, Geneva," Bref-introduction, Administration, Scoring and Generic -Version of the assessment, Available: https://www.who.int/mental_health/media/en/76.pdf?ua=1 (accessed Dec. 18, 2020).

[25] WHOQOL (2021) "Measuring Quality of Life," Available: https://www.who.int/healthinfo/survey/whoqol-qualityoflife/en/ (accessed Dec. 18, 2020).

[26] World Resources Institute (WRI) (2015), "Cities Safer by Design, Urban Design Recommendations for Healthier Cities, Fewer Traffic Fatalities," Available: https://www.wri.org/publication/cities-safer-design (accessed Dec. 25, 2020).

[27] Youssef M.S., (1983), "Mental Image of the City," Available: http://repository.sustech.edu/bitstream/handle/123456789/14449/\%D9\% $85 \% \mathrm{D} 9 \% 84 \% \mathrm{D} 8 \% \mathrm{AD} \% \mathrm{D} 9 \% 82 \% 20$ pdf? sequence $=2$ \&isAllowed=y (accessed Dec. 08, 2020).

\section{Title Arabic:}

( ) إعادة تأهيل شبكات الطرق داخل الأحياء المتأصلة وتأثير ها على جودة :

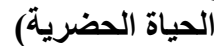
دراسة حالة: حي" مصر الجديدة" ـ القاهرة

\section{Arabic Abstract:}

حي "هليوبوليس" احد أرقى أحياء القاهرة، أنشأه البارون إمبان البلجيكي شمال

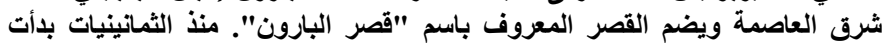

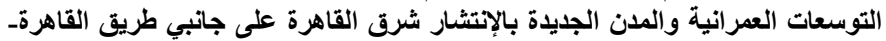

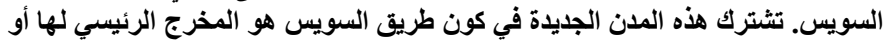

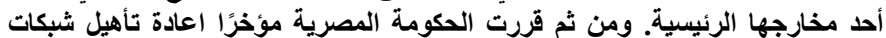

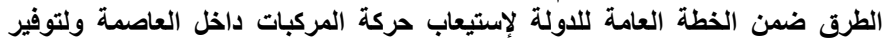

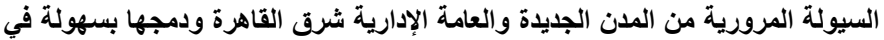

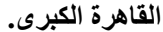

يهرف البحث إلى تحديد الأبعاد المادية وغير المادية لإعادة تأهيل شبكات الطرق التي

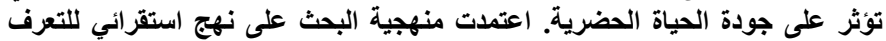

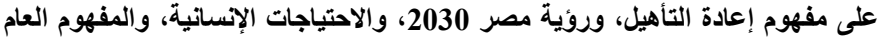

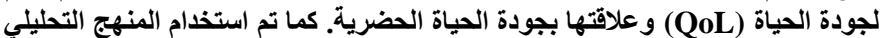

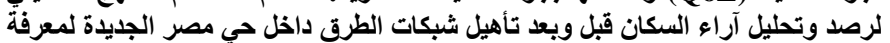
تأثير ذلك على جودة الحياة الحضرية.

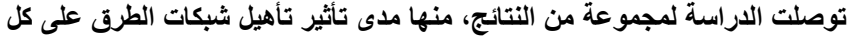

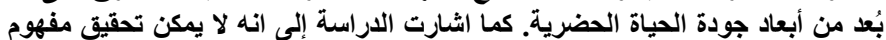

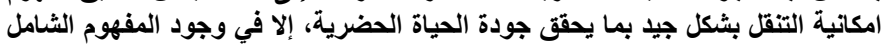
لحركة المشاة والسيارات والنقل العام والاراجات في منظومة الأل عمل واحدة حتي يتحقق

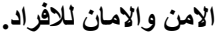

